\title{
Pengaruh Pengeluaran Pemerintah dan Tingkat Pengangguran Terbuka (TPT) terhadap Pertumbuhan Ekonomi Inklusif Indonesia
}

\author{
Silvi Dewi Purwanti ${ }^{1)}$, Farida Rahmawati ${ }^{2 *}$ \\ 1)2) Economics and Development Study, Faculty Of Economics and Business, Universitas Negeri Malang, \\ Malang City, Indonesia \\ *E-mail corresponding author: farida.rahmawati.fe@um.ac.id
}

Received: 27-02-2021;

Accepted: 31-03-2021;

Available online: $30-04-2021$

Ecoplan Vol. 4 No. 1, April 2021, hlm 32-44.

\section{ISSN p: 2620-6102 \\ e: 2615-5575}

Abstract - This research is motivated by economic growth, a goal for a country supported by economic development. However, economic growth in Indonesia during the years 2010-2019 has not shown an ever-increasing result at the national level, and poverty and inequality have not been able to decrease. This condition is contrary to the goal of achieving inclusive economic growth. This study aims to measure and analyze Inclusive Economic Growth and the factors that influence it. This study uses two analysis methods: the PovertyEquivalent Growth Rate (PEGR) model analysis and multiple linear regression analysis with time-series data. The results show that inclusive economic growth in Indonesia has not been consistent every year in the last decade. The time-series data regression analysis results show that the variables of government spending on education and spending on health have a significant effect on inclusive economic growth. The government expenditure variable in education has an inversely proportional impact on inclusive economic growth, while the open unemployment rate (TPT) variable has no significant effect on inclusive economic growth. Efforts that can be made through government policy implications are strengthening the Smart Indonesia Program (PIP) to vocational education. Health facilities, health programs through additional facilities, recruitment of medical personnel to maximize health Indonesia cards, and BPJS.

Abstrak - Penelitian ini dilatarbelakangi oleh adanya peningkatan pertumbuhan ekonomi merupakan tujuan bagi suatu Negara, yang didukung dengan pembangunan ekonomi. Namun pertumbuhan ekonomi di Indonesia selama tahun 2010-2019 belum menunjukkan hasil yang terus meningkat pada level nasional disamping itu kemiskinan dan ketimpangan yang belum dapat menurun. Kondisi tersebut bertolakbelakang dengan tujuan tercapainya pertumbuhan ekonomi inklusif. Penelitian ini bertujuan untuk mengukur dan menganalisis Pertumbuhan Ekonomi Inklusif dan faktor-faktor yang mempengaruhinya. Terdapat dua metode analisis yang digunakan dalam penelitian ini, yaitu analisis model Poverty-Equivalent Growth Rate (PEGR) dan analisis regresi linier berganda dengan data time series. Hasil penelitian menunjukan bahwa pada satu dekade terakhir pertumbuhan ekonomi inklusif di Indonesia belum konsisten tercapai setiap tahun. Hasil analisis regresi data time series menunjukkan bahwa variabel pengeluaran pemerintah bidang pendidikan dan pengeluaran pemerintah bidang kesehatan berpengaruh signifikan terhadap pertumbuhan ekonomi inklusif. Variabel pengeluaran pemerintah bidang pendidikan memiliki pengaruh yang berbanding terbalik terhadap pertumbuhan ekonomi inklusif, Sedangkan variabel tingkat pengangguran terbuka (TPT) berpengaruh tidak signifikan tehadap pertumbuhan ekonomi inklusif. Adapun upaya yang dapat dilakukan melalui impikasi kebijakan pemerintah yaitu penguatan Program Indonesia Pintar (PIP), hingga pendidikan vokasi, penguatan 
program kesehatan melalui penambahan fasilitas kesehatan, perekrutan tenaga medis, hingga memaksimalkan kartu Indonesia sehat dan BPJS.

Kata Kunci : Pengeluaran Pemerintah, TPT, Pertumbuhan Ekonomi Inklusif.

\section{PENDAHULUAN}

Setiap negara pasti memiliki tujuan untuk meningkatkan pertumbuhan ekonomi. Pertumbuhan ekonomi di suatu negara akan dapat dicapai apabila pembangunan ekonomi juga dapat terpenuhi. Menurut (Sukirno, 2011) bahwa pembangunan ekonomi adalah pertumbuhan ekonomi yang ditambah dengan perubahan, sehingga artinya pembangunan ekonomi tidak hanya diukur dari kenaikan produksi barang dan jasa yang berlaku dari tahun ke tahun melainkan juga perlu diukur aspek lainnya seperti perkembangan pendidikan, perkembangan teknologi, peningkatan kesehatan, peningkatan ketersediaan infrastruktur, peningkatan pendapatan hingga kemakmuran masyarakat.

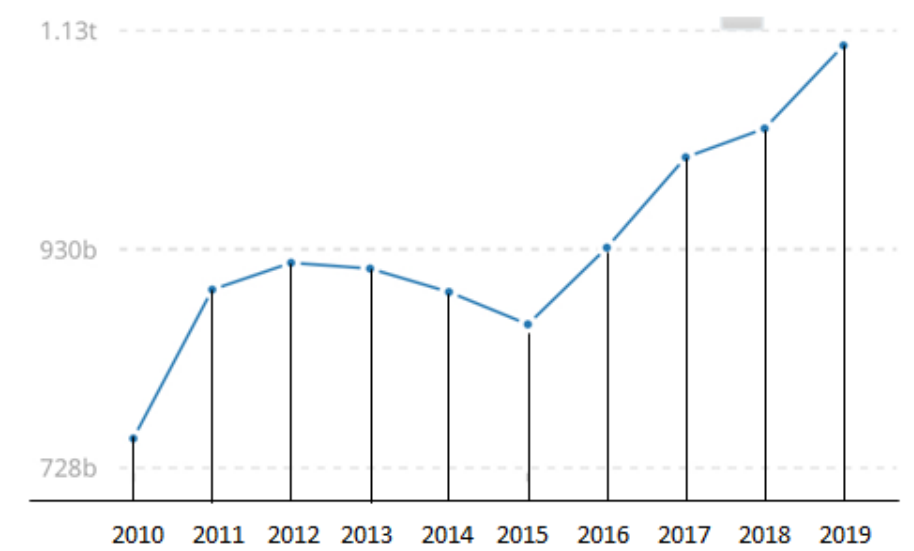

Gambar 1. Pertumbuhan Ekonomi Indonesia

Sumber: World Bank

Pertumbuhan ekonomi Indonesia menunjukkan perkembangan yang berfluktuatif. Perkembangan pertumbuhan ekonomi tersebut dapat disebabkan oleh beberapa faktor baik dari faktor ekonomi maupun non ekonomi. Faktor ekonomi dapat berupa kebijakan pemerintah seperti kebijakan fiskal dan kebijakan moneter, kondisi ekonomi negara lain dsb dan faktor non ekonomi seperti bencana alam, sosial budaya, dan lain-lain. Terdapat beberapa permasalahan ekonomi yang terjadi di negara ini. Salah satu nya yang utama yaitu tingkat kemiskinan. Tingkat kemiskinan di Indonesia masih menunjukkan angka yang cukup tinggi.

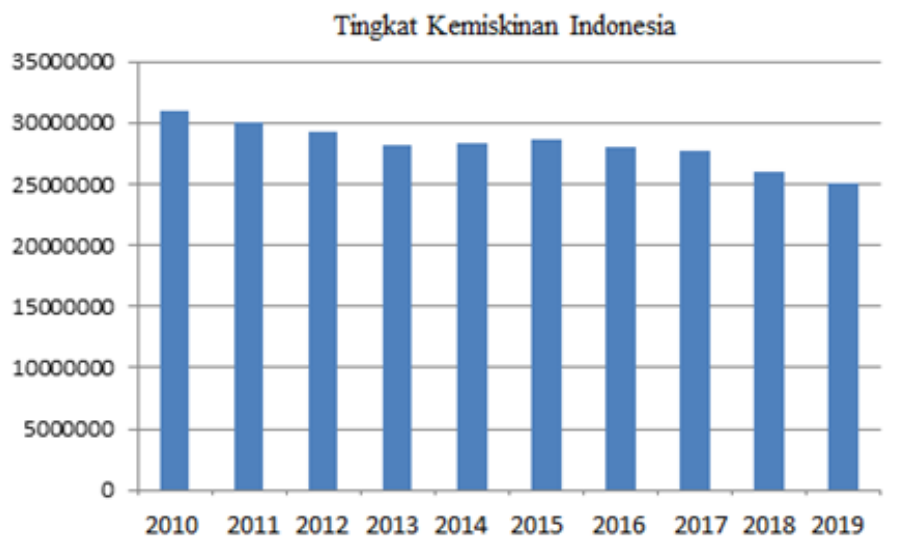

Gambar 2. Tingkat Kemiskinan Indonesia

Sumber: Badan Pusat Statistik Indonesia (data diolah)

Dilihat dari diagram Gambar 2, data menunjukkan bahwa jumlah penduduk miskin di Indonesia yang cukup tinggi dari tahun ke tahun, penurunan yang belum cukup menunjukkan ke arah yang signifikan. Social Mobility Index (SMI) yang dirilis oleh World Economic Forum menunjukkan posisi 
suatu negara dengan tingkat keadaan kemiskinannya. Meskipun di Indonesia tingkat kemiskinan dalam beberapa tahun mengalami penurunan namun kenyataan nya kondisi pertumbuhan ekonomi belum merata kebermanfaatnya. Hal ini juga dapat dilihat dan dinilai melalui Social Mobility Index. Pada Gambar 3 merupakan Social Mobility Index tahun 2019 yang dipublikasi kan oleh World Economic Forum, Indonesia menempati urutan ke 67 dari 82 negara.

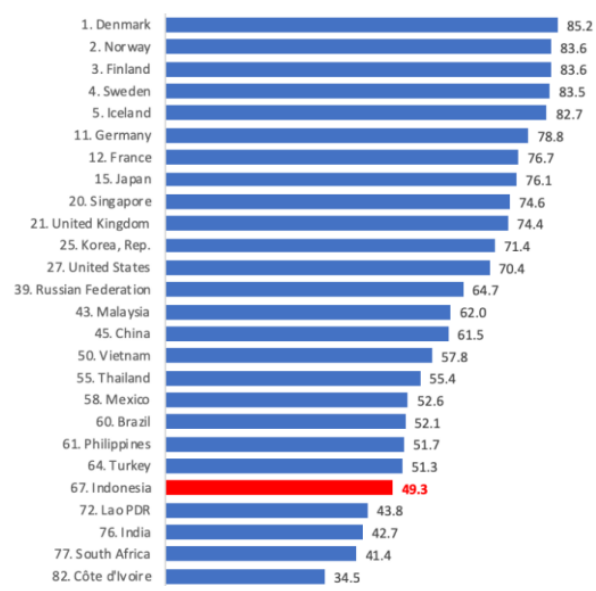

Gambar 3. Social Mobility Index

Sumber: World Economic Forum

Semakin tinggi nilai Social Mobility Index maka akan semakin rendah ketimpangan pada suatu negara tersebut. Indonesia menempati tingkat Social Mobility Index yang cukup rendah, sehingga hal ini menunjukkan bahwa tingkat ketergantungan kondisi ekonomi individu terhadap orang tua masih cukup tinggi, yang artinya masyarakat dari keluarga dengan ekonomi menengah ke bawah akan mengalami kondisi ekonomi menegah ke bawah pula. Sehingga kemungkinan anak dari keluarga miskin sulit memperbaiki kondisi ekonomi yang akan menyumbang angka kemiskinan. Dari tingkat kemiskinan tersebut terdapat hubungan dengan ketimpangan yang terjadi di Indonesia. Ketimpangan yang terjadi di Indonesia digambarkan dari distribusi PDB yang ada di Indonesia masih banyak dikuasai oleh provinsiprovinsi di Indonesia Bagian Barat, sehingga beberapa kawasan di Indonesia masih menunjukkan kondisi yang masih tertinggal dalam hal ketersediaan prasarana fisik, sosial hingga sumber daya maupun kelembagaannya.

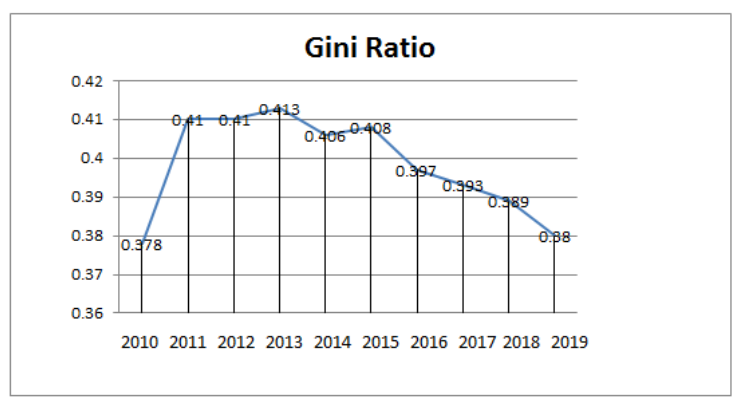

\section{Gambar 4. Gini Ratio Indonesia}

Sumber: Badan Pusat Statistik (data diolah)

Ketimpangan yang di Indonesia juga tergambar dalam data gini ratio. Dengan nilai gini ratio yang cukup tinggi menunjukkan bahwa ketimpangan pendapatan di Indonesia masih cukup tinggi. Dengan adanya pertumbuhan ekonomi yang kebermanfaatanya belum dirasakan oleh seluruh lapisan masyarakat, maka hal tersebut dapat dinilai dari pertumbuhan ekonomi dengan tingkat kemiskinan yang masih tinggi, adanya ketimpangan yang masih tinggi pula. Persoalan kemisikinan dan kesenjangan yang terjadi tentu bertolak belakang dengan isu pertumbuhan inklusif. Sehingga pencapaian pertumbuhan ekonomi inklusif di Indonesia masih cukup kurang. Definisi pertumbuhan inklusif disini yaitu, pertumbuhan ekonomi dapat disebut inklusif apabila pertumbuhan ekonomi tersebut mampu menurunkan kemiskinan, ketimpangan distribusi pendapatan dan meningkatkan penyerapan tenaga kerja.

Pembangunan sumber daya manusia merupakan prioritas pembangunan pemerintah pada rencana pembangunan satu dekade dalam dua periode yaitu 2010-2014 dan pada 2015-2019. Peningkatan kualitas 
sumberdaya manusia tersebut dapat dicapai melalui peningkatan pendidikan dan kesehatan. Namun kondisi pendidikan di Indonesia saat ini belum menunjukkan peningkatan yang baik karena dapat dilihat dari Gambar 5.

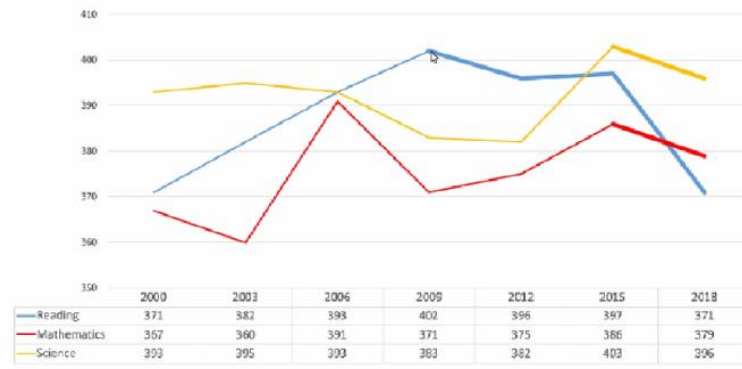

Gambar 5. PISA score: Indonesia, 2000-2018

Sumber: OECD, PISA 2018

Dari Gambar 5 menunjukkan dari penilaian membaca maupun pengetahuan, meskipun di Indonesia jumlah anak bersekolah terus meningkat, tetapi kemampuan pemahamannya belum menunjukkan peningkatan, sehingga belum baik. Selain pendidikan, kesehatan juga memerlukan perhatian khusus untuk menghasilkan sumber daya manusia yang dapat memiliki pendidikan yang baik pula.

Pemerintah memiliki beberapa kebijakan yang dapat mempengaruhi peningkatan pertumbuhan ekonomi dan kualitas sumberdaya manusia serta menurunkan permasalahan pembangunan yang terjadi. Salah satu kebijakan di Indonesia adalah kebijakan fiskal, yang dapat mendukung peningkatan sumberdaya manusia khususnya pengeluaran pemerintah melalui pengeluaran di bidang pendidikan dan pengeluaran pemerintah dibidang kesehatan, untuk mengurangi kemiskinan dan ketimpangan sehingga mengarah kepada pemerataan pembangunan. Selain dari pembangunan pada kualitas sumber daya manusia itu sendiri, adanya jumlah tenaga kerja yang produktif juga merupakan hal penting dalam mendukung pembangunan, karena apabila terjadi peningkatan tenaga kerja produktif maka output perekonomian juga dapat meningkat, namun hal tersebut juga harus diimbangi dengan adanya suatu sarana atau prasarana yang mendukung, baik berupa kebijakan ataupun yang lainnya. Sehingga peningkatan tenaga kerja yang produktif atau biasa tergolong dalam angkatan kerja dapat terserap dalam lapangan kerja yang tinggi pula dan dapat meningkatkan pertumbuhan ekonomi dalam mencapai inklusifitas. Namun kondisi angkatan kerja di Indonesia pada tahun 2010-2019 masih perlu adanya fokus lebih lanjut karena angka pengangguran cenderung meningkat dari tahun ke tahun.

\section{TINJAUAN PUSTAKA}

Pertumbuhan Ekonomi

Pertumbuhan ekonomi memiliki arti yaitu sebagai kenaikan GDP/GNP tanpa memandang apakah kenaikan itu lebih besar atau lebih kecil dari tingkat pertumbuhan penduduk, dan kondisi dimana terjadi adanya perubahan struktur ekonomi atau tidak. Teori pertumbuhan ekonomi menurut solow sangat tergantung pada pertambahan faktor-faktor produksi, diantaranya yaitu tenaga kerja, akumulasi modal serta kemajuan teknologi (Prasetyo \& Sulistyaningrum, 2013).

\section{Pertumbuhan Ekonomi Inklusif}

Menurut Asian Development Bank (ADB) dalam (Klasen, 2010) menyarankan bahwa penting untuk menentukan episode ekonomi seperti apa yang memiliki karakteristik sebagai pertumbuhan yang inklusif. Maka terdapat suatu kemungkinan untuk melihat hal tersebut, yang pertama yaitu melalui proses, pertumbuhan ekonomi yang inklusif merupakan meluasnya pertumbuhan antar sektor atau intensif terhadap tenaga kerja, maka dari itu pertumbuhan inklusif dapat diartikan sebagai pertumbuhan yang melibatkan partisipasi semua pihak tanpa diskriminasi dan mampu melibatkan seluruh sektor ekonomi. Yang kedua dilihat melalui hasil dari proses pertumbuhan, dalam hal ini konsep pertumbuhan inklusif berkaitan erat dengan konsep pertumbuhan pro poor, yang berarti berdasarkan hasil yang dicapainya, pertumbuhan inklusif merupakan pertumbuhan yang mampu mempengaruhi untuk penurunan kelompok yang "tidak diuntungkan" di dalam perekonomian. Berdasarkan hal tersebut pertumbuhan inklusif dapat disebut pertumbuhan yang tidak mendiskriminasi dan mampu menjamin pemerataan akses pertumbuhan atau, juga dapat dikatakan sebagai pengurangan disparitas antar kelompok. 
Menurut (Azwar, 2016) dengan pendekatan yang dirumuskan oleh Klassen (2010), dengan mengadopsi uraian mengenai konsep PEGR maka untuk menghitung pertumbuhan inklusif sebagai berikut :

$$
\mathrm{IGij}=\frac{\mathrm{Gij}}{\bar{G} j} * \frac{-}{G j}
$$

Keterangan :

IGij = Koefisien pertumbuhan inklusif

Gij = Pertumbuhan kelompok i dalam kaitannya dengan indikator $\mathrm{j}$

$\mathrm{Gj}=$ Pertumbuhan indikator $\mathrm{j}$

Dalam hal ini i mengacu pada kelompok kurang beruntung tertentu dan j mengacu pada indikator yang bersangkutan (misalnya, pertumbuhan pendapatan atau ekspansi dalam pendidikan). Dari konsep PEGR yang digunakan untuk menghitung elastisitas sebagai komponen dalam setiap perhitungan koefisien inklusif dapat diturunkan. Dengan menjabarkan kemiskinan (p), ketimpangan (in) dan tenaga kerja (em), dan j mengacu pada indikator pertumbuhan ekonomi (g), maka pertumbuhan inklusif dapat diukur dengan rumusan tiga pendekatan berikut ini :

1. Pertumbuhan inklusif dalam menurunkan kemiskinan, koefisiennya adalah:

$$
\mathrm{IGp}=(\mathrm{Gpg} / \mathrm{Gp}) \hat{\mathrm{G} g}
$$

2. Pertumbuhan inklusif dalam menurunkan ketimpangan, maka koefisiennya :

$$
\mathrm{IGin}=(\mathrm{Gin} . \mathrm{g} / \mathrm{Gin}) \hat{\mathrm{Gg}}
$$

3. Pertumbuhan inklusif dalam meningkatkan penyerapan tenaga kerja, maka koefisiennya sebagai berikut :

$$
\mathrm{IGem}=(\text { Gem.g } / \text { Gem }) \hat{\text { Geg }}
$$

\section{Pengeluaran Pemerintah}

Melalui kebijakan fiskal, pemerintah dapat melakukan redistribusi pendapatan melalui pengeluaran pemerintah dan perpajakan. Ostry (2014) dalam Utama et al., (2017) menyatakan bahwa melalui program redistribusi pendapatan yang melalui investasi untuk infrastruktur, kesehatan, pendidikan, jaminan sosial akan berdampak pada pertumbuhan ekonomi dan pemerataan. Adolf Wegner memiliki pendapat, dalam suatu bentuk hukum apabila pendapatan perkapita meningkat maka secara relatif pengeluaran pemerintah akan meningkat pula terutama disebabkan karena pemerintah harus mengatur hubungan yang timbul di dalam masyarakat, hukum, pendidikan, rekreasi, kebudayaan dan sebagainya (Mangkoesoebroto,1997; Wibowo, 2014).

\section{Tingkat Pengangguran}

Menurut (BPS) Pengganguran merupakan penduduk yang termasuk masyarakat produktif dan tergolong dalam angkatan kerja, dimana mereka juga ingin memiliki pekerjaan namun masih belum mendapatkan pekerjaan tersebut. Hal ini dapat terjadi karena kurang nya kesesuaian yang terjadi pada pasar tenaga kerja, dimana dengan adanya kelebihan penawaran tenaga kerja namun kondisi permintaan tenaga kerja yang hanya sedikit. Adapun perhitungan tingkat pengganguran terbuka yaitu sebagai berikut:

$$
\text { Tingkat Pengangguran }=\frac{\text { Jumlah Pengangguran }}{\text { Jumlah Angkatan Kerja }}+100 \%
$$




\section{METODE PENELITIAN}

Jenis penelitian yang digunakan pada penelitian ini adalah penelitian kuantitatif deskriptif. Jenis data yang digunakan dalam penelitian ini yaitu data sekunder, dimana data yang diperoleh bersumber dari Publikasi Online dari World Bank, Badan Pusat Statistik (BPS) serta Kementrian Keuangan. Dengan menggunakan variabel dependen (terikat) yaitu Pertumbuhan Ekonomi Inklusif Indoensia tahun 20102019, sedangkan untuk variabel independent (bebas) menggunakan data Pengeluaran Pemerintah Bidang Pendidikan Indonesia tahun 2010-2019, Pengeluaran Pemerintah Bidang Kesehatan Indonesia tahun 2010-2019 dan Tingkat Pengganguran Terbuka (TPT) Indonesia tahun 2010-2019. Data yang digunakan dalam penelitian ini yaitu data pada level nasional. Teknik pengumpulan data yang dilakukan oleh peneliti adalah menggunakan teknik dokumentasi. Pada penelitian ini digunakan dua metode analisis data, sebagai berikut:

\section{Spesifikasi Model Poverty-Equivalent Growth Rate (PEGR)}

Analisis deskriptif yang digunakan oleh peneliti untuk menganalisis kondisi pertumbuhan ekonomi inklusif di Indonesia. Analisis data menggunakan excel. Pengukuran pertumbuhan ekonomi inklusif dengan konsep PEGR meliputi tiga dimensi pengukuran. Perhitungan dengan metode PEGR merupakan metode yang relevan untuk digunakan menghitung koefisien pertumbuhan ekonomi inklusif dengan membandingkan data keadaan kemiskinan, distribusi pendapatan, dan rata-rata penduduk pada awal periode dengan keadaan pada akhir periode atau disebut dengan teknik analisis ex-post, karena jika menggunakan teknik analisis ex-ante tidak memungkinkan jika melalui Kurva Lorenz. Peneliti mengadopsi salah satu diantaranya yaitu pengukuran pertumbuhan ekonomi inklusif dalam mengurangi kemiskinan. Dengan menggunakan analisis deskriptif akan dilihat tingkat pertumbuhan ekonomi inklusif di Indonesia setiap tahunnya.

Di mana dengan mengusung hasil pengembangan konsep oleh Klassen (2010) dalam (Amalina et al., 2013) penelitian ini menggunakan indikator kemiskinan, dengan menjabarkan i sebagai kemiskinan (p) yang mengacu pada indikator pertumbuhan ekonomi (g), maka model analisis terkait fenomena inklusifitas pertumbuhan yang digunakan adalah sebagai berikut:

$\mathrm{IGp}=(\mathrm{Gpg} / \mathrm{Gp}) \hat{\mathrm{G} g}$

Di mana:

IGp : koefisien pertumbuhan inklusif dalam menurunkan kemiskinan

$\mathrm{Gp} \quad$ : elastisitas kemiskinan terhadap pendapatan rata-rata

Gpg : elastisitas kemiskinan terhadap pertumbuhan ekonomi

$\hat{\mathrm{G} g} \quad$ : pertumbuhan ekonomi

IGp menyatakan inklusifitas pertumbuhan dalam menurunkan kemiskinan, sehingga pertumbuhan dinyatakan inklusif apabila nilai IGp $>\hat{G} g$. PEGR.

Nilai Gpg dan Gp pada persamaan 1 di atas diperoleh dengan cara yang sama dalam konsep

Dengan mendefinisikan kemiskinan $(\mathrm{P})$ sebagai fungsi dari jumlah penduduk miskin $(\mathrm{z})$ dan pendapatan rata-rata penduduk (x) yang dirumuskan sebagai berikut:

$\mathrm{P}=\mathrm{P}(\mathrm{z}, \mathrm{x})$

Maka perubahan persentase jumlah penduduk miskin pada periode 1 dan periode 2 dapat dituliskan sebagai berikut ini:

$\mathrm{P} 12=\mathrm{P} 2-\mathrm{P} 1=\operatorname{Ln}[\mathrm{P}(\mathrm{z} 2, \mathrm{x} 2)]-\operatorname{Ln}[\mathrm{P}(\mathrm{z} 1, \mathrm{x} 1)]$

Dan perubahan persentase pendapatan rata-rata penduduk dapat dihitung sebagai:

$\Psi=\operatorname{Ln}(x 2)-\operatorname{Ln}(x 1)$ sebagai:

Dengan demikian elastisitas kemiskinan terhadap pendapatan rata-rata $(\mathrm{Gp})$ dapat dihitung

$\mathrm{Gp}=\mathrm{P} 12 / \Psi$

Sementara perubahan pertumbuhan ekonomi (Ĝg) yang dihitung dari Produk Domestik Bruto (PDB), sehingga perubahan pertumbuhan ekonomi periode 1 dan periode 2 dapat dituliskan sebagai:

$\hat{\mathrm{G} g}=\operatorname{Ln}(\mathrm{PDRB} 2)-\mathrm{Ln}(\mathrm{PDRB} 1)$ sebagai :

Dengan demikian, elastisias kemiskinan terhadap pertumbuhan ekonomi (Gpg) dapat dihitung

$\mathrm{Gpg}=\mathrm{P} 12 / \hat{\mathrm{G} g}$

Hasil yang diperoleh dari perhitungan persamaan (5) dan (7) diatas kemudian dimasukkan ke dalam persamaan (1) untuk memperoleh nilai indeks pertumbuhan inklusif yang kemudian digunakan untuk dibandingkan dengan nilai pertumbuhan ekonomi ( $\hat{G} g)$. 


\section{Spesifikasi Model Regresi}

Analisis data menggunakan software Stata 14.0. Metode analisis yang digunakan didalam penelitian ini adalah regresi linier berganda dengan jenis penelitian yang menggunakan deret waktu dan dengan lokasi penelitian di satu tempat.

Berikut merupakan model analisis regresi dengan data time series yang digunakan dalam penelitian ini adalah :

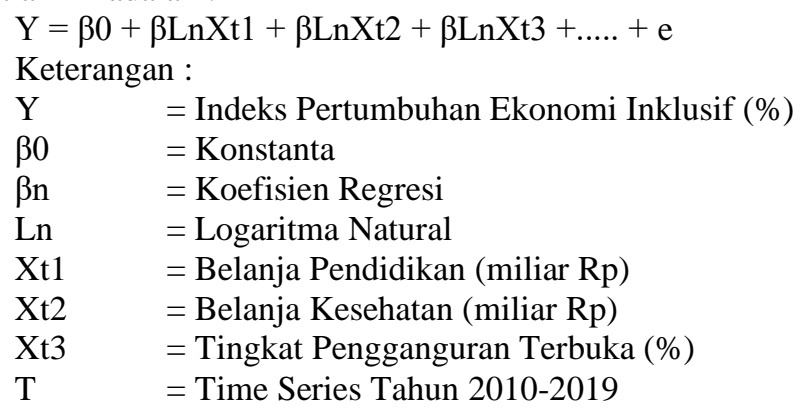

HASIL DAN PEMBAHASAN

Hasil Analisis Model Poverty-Equivalent Growth Rate (PEGR)

Tabel 1. Analisis Model PEGR

\begin{tabular}{cccc}
\hline Tahun & Gg & IGp & Hasil \\
\hline 2010 & -0.33 & -0.32 & tidak inklusif \\
2011 & -0.16 & -0.15 & tidak inklusif \\
2012 & -0.02 & -0.01 & tidak inklusif \\
2013 & 0.005 & 0.019 & inklusif \\
2014 & 0.02 & 0.03 & inklusif \\
2015 & 0.03 & 0.04 & inklusif \\
2016 & -0.07 & -0.06 & tidak inklusif \\
2017 & -0.08 & -0.07 & tidak inklusif \\
2018 & -0.02 & -0.01 & tidak inklusif \\
2019 & -0.07 & -0.06 & tidak inklusif \\
\hline
\end{tabular}

Sumber: data diolah (2020)

Tabel 1 menunjukkan bahwa pada beberapa periode penelitian, nilai koefisien pertumbuhan inklusif di Indonesia tidak pernah konsisten mencapai pertumbuhan yang inklusif, pada tahun 2010-2012 kondisi pertumbuhan ekonomi dalam mengurangi kemiskinan tidak inklusif, berbeda dengan tahun 20132015 kondisi pertumbuhan ekonomi dalam mengurangi kemiskinan di Indonesia dapat inklusif. Namun pada tahun selanjutnya 2016-2019 dengan Pertumbuhan Ekonomi yang terus mengalami kenaikan tetapi Pertumbuhan tersebut tidak inklusif dalam mengurangi kemiskinan. Dari hasil tersebut pada tahun 2011 dan tahun 2012 pertumbuhan ekonomi menunjukkan angka peningkatan namun dalam tabel menunjukkan pertumbuhan ekonomi tersebut tidak inklusif dalam menurunkan kemiskinan, begitu pula pada tahun 2016 hingga tahun 2019 menunjukkan peningkatan meskipun tahun 2018 sedikit mengalami penurunan, namun inklusifitas pertumbuhan ekonomi belum dapat tercapai pada tahun-tahun tersebut. Oleh karena itu, untuk mewujudkan Pertumbuhan Ekonomi ke arah Pro-Poor, maka terdapat faktor-faktor yang dapat mempengaruhi Pertumbuhan Ekonomi Inklusif di Indonesia khususnya dalam mengurangi kemiskinan. 
Hasil Analisis Statistik Regresi Data Time Series

\begin{tabular}{|c|c|c|c|c|c|c|}
\hline Source & ss & df & MS & \multirow{3}{*}{\multicolumn{2}{|c|}{$\begin{array}{l}\text { Number of obs } \\
F(3,6) \\
\text { Prob > F }\end{array}$}} & \multirow{2}{*}{$\begin{array}{r}10 \\
6.90 \\
0.0226\end{array}$} \\
\hline Model & .08487791 & 3 & .028292637 & & & \\
\hline Residual & .024586771 & 6 & .004097795 & & $\begin{array}{l}\text { R-squared } \\
\text { Adj R-squared }\end{array}$ & 0.7754 \\
\hline Total & .109464681 & 9 & .012162742 & $\begin{array}{l}\text { Adj } \\
\text { Root }\end{array}$ & $\begin{array}{l}\text { R-squared } \\
\text { MSE }\end{array}$ & $\begin{array}{l}0.6631 \\
.06401\end{array}$ \\
\hline igp & Coef. & Std. Err. & t & $p>|t|$ & [958 Conf. & Interval] \\
\hline In_pend & 1.040116 & .2823109 & 3.68 & 0.010 & .3493265 & 1.730906 \\
\hline ln_kes & -.4528105 & .1532369 & -2.95 & 0.025 & -.8277676 & -.0778534 \\
\hline ln_tpt & -.215043 & .2768042 & -0.78 & 0.467 & -.8923584 & .4622723 \\
\hline cons & -7.944031 & 2.708159 & -2.93 & 0.026 & -14.57066 & -1.317406 \\
\hline
\end{tabular}

\section{Gambar 6. Hasil Regresi aplikasi Stata 14.0}

Sumber: data diolah (2020)

Berdasarkan Gambar 6 menunjukkan regresi data time series, dengan hasil uji koefisien determinasi $\left(\mathrm{R}^{2}\right)$ bahwa masing-masing variabel pengeluaran pemerintah bidang pendidikan, pengeluaran pemerintah bidang kesehatan, dan tingkat pengangguran terbuka dalam menjelaskan variabel terikat yaitu pertumbuhan ekonomi inklusif sebesar $77.54 \%$. Dan sisanya sebesar $22.46 \%$ dijelaskan oleh variabel lain diluar model. Dari hasil uji parsial menunjukkan bahwa variabel pengeluaran pemerintah bidang pendidikan berpengaruh signifikan terhadap pertumbuhan ekonomi inklusif namun memiliki koefisien pertumbuhan ekonomi inklusif negatif. Variabel pengeluaran pemerintah bidang kesehatan berpengaruh signifikan terhadap pertumbuhan ekonomi inklusif. Variabel tingkat pengangguran terbuka (TPT) berpengaruh tidak signifikan terhadap pertumbuhan ekonomi inklusif.

Dari tiga variabel bebas dan satu variabel terikat yang digunakan dalam penelitian ini maka diperoleh model sebagai berikut :

IPEI = -7.944031+1.040116 Belanja Pendidikan - 0.4528105 Belanja Kesehatan - 0.215043 TPT $+\mathrm{e}$

Dari hasil pengolahan data, variabel pengeluaran pemerintah bidang pendidikan memiliki pengaruh signifikan terhadap pertumbuhan ekonomi inklusif. Dengan nilai probabilitas $0.010<0.05$. Yang artinya ketika belanja pendidikan menurun 1 miliar $\mathrm{Rp}$, maka pertumbuhan ekonomi inklusif akan meningkat 1.040116 sebesar persen secara rata-rata, dengan asumsi variabel lain tidak berubah. Menurut teori, pengeluaran pemerintah termasuk suatu kebijakan pemerintah, yaitu kebijakan fiskal, yang bertujuan untuk mengontrol stabilitas ekonomi maupun sosial melalui distribusi pendapatan. Pengeluaran pemerintah pada bidang pendidikan merupakan suatu bentuk kebijakan yaitu investasi terhadap sumber daya manusia. Melalui pengeluaran pemerintah khususnya bidang pendidikan, pemerintah dapat mengambil kebijakan melalui secara umum perbaikan sistem pendidikan yang lebih modern, mengadakan pembangunan sarana dan prasarana pendidikan. Dengan hal tersebut kemajuan teknologi sangat perlu selaras dengan adanya perbaikan peningkatan kualitas sumber daya manusia. Secara luas ketika teknologi dapat disebarkan di seluruh wilayah di Indonesia maka juga akan meningkatkan kemampuan dari transfer ilmu pengetahuan antar wilayah yang mereka tidak bisa dapatkan di daerah mereka serta kreatifitas masyarakat, hal ini tidak hanya dapat mendorong output secara agregat namun juga akan dapat mendorong terbukanya lapangan pekerjaan secara merata.

Namun upaya pemerintah dalam satu dekade tersebut belum menunjukkan hasil yang maksimal sehingga pengeluaran pemerintah pada bidang pendidikan ketika menurun dapat meningkatkan pertumbuhan ekonomi inklusif. Hal ini terjadi karena jumlah angkatan kerja di Indonesia meningkat dari tahun ke tahun pada Gambar 7, angkatan kerja tersebut sebagian besar merupakan penduduk dari lulusan pendidikan hingga menengah ke atas. Namun tingkat pengganguran juga belum mampu menurun setiap tahunnya pada Gambar 8, sehingga tingkat pendidikan mencerminkan belum maksimal dalam mendorong pertumbuhan ekonomi inklusif melalui pengeluaran pemerintah bidang pendidikan. Hal tersebut juga dapat disebabkan bahwa jasa atau akses pendidikan yang memadai belum banyak dirasakan oleh masyarakat dengan kondisi ekonomi menengah ke bawah, sehingga pada saat tertentu memperburuk distribusi pendapatan, sehingga hal tersebut bertolak belakang dengan konsep pertumbuhan ekonomi yang inklusif. Hal ini sejalan dengan penelitian Azwar (2016) bahwa indeks pendidikan memiliki pengaruh yang negatif dan signifikan terhadap pertumbuhan ekonomi inklusif. Dan tidak sesuai dengan 
penelitian menurut Prabandari \& Santoso (2018) bahwa fiscal policy melalui anggaran pendidikan dan kesehatan memiliki pengaruh terhadap pertumbuhan inklusif dimana akses pendidikan terutama untuk masyarakat miskin terbuka sehingga produktivitas masyarakat tersebut dapat meningkat, dengan adanya peningkatan produktivitas dapat meningkatkan penghasilan maka akan membantu masyarakat dari kondisi dengan ekonomi yang rendah maka secara otomatis akan mengurangi ketimpangan.

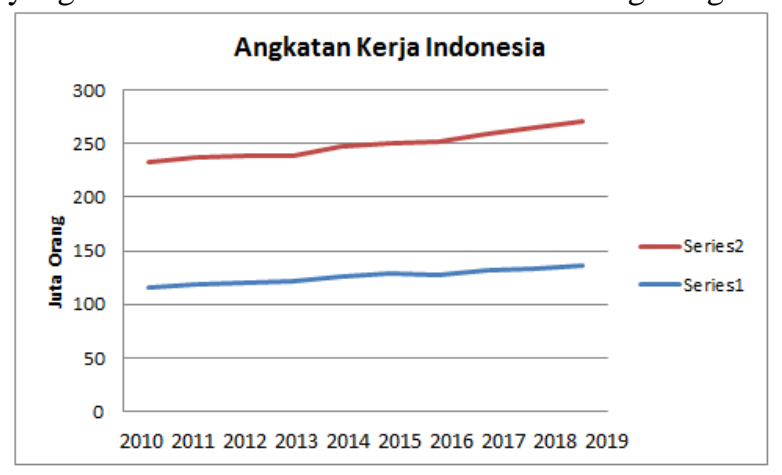

Gambar 7. Jumlah Angkatan Kerja di Indonesia tahun 2010-2019

Sumber: Badan Pusat Statistik Indonesia, (data diolah)

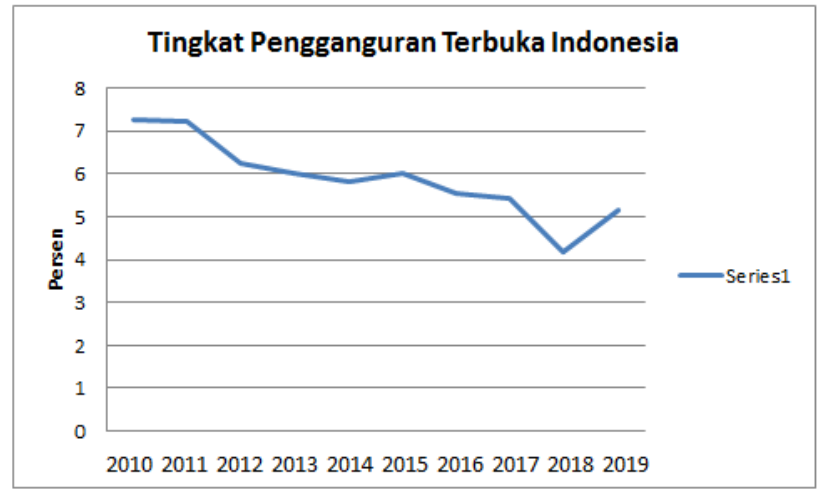

Gambar 8. Tingkat Pengganguran Terbuka di Indonesia tahun 2010-2019

Sumber: Badan Pusat Statistik Indonesia, data diolah

Variabel pengeluaran pemerintah bidang kesehatan memiliki pengaruh signifikan terhadap pertumbuhan ekonomi inklusif. Dengan nilai probabilitas $0.025<0.05$. Artinya ketika belanja kesehatan menurun sebesar 1 miliar Rp, maka pertumbuhan ekonomi inklusif akan menurun sebesar 0.4528105 persen secara rata-rata, dengan asumsi variabel lain tidak berubah. Begitupun sebaliknya apabila belanja kesehatan meningkat maka pertumbuhan ekonomi inklusif akan meningkat. Hal ini sesuai dengan teori Wagner, pengeluaran pemerintah akan meningkat karena adanya interaksi dalam masyarakat yang salah satu nya yaitu pada perbaikan tingkat kesehatan. Pengeluaran pemerintah bidang kesehatan juga termasuk dalam investasi modal manusia, karena kebutuhan mendasar manusia adalah kesehatan, sehingga pembangunan kesehatan melalui pengeluaran pemerintah juga merupakan suatu kebijakan yang terus ditingkatkan oleh pemerintah. Sehingga meningkatnya produktivitas juga terjadi karena dari peningkatan pada tingkat kesehatan masyarakat. Hal tersebut yang dapat mendorong pertumbuhan ekonomi yang dibarengi dengan peningkatan pembangunan sumber daya manusia sehingga masyarakat dapat berupaya menyesuaikan dalam pasar tenaga kerja sehingga dapat mengarah pada percepatan pencapaian pertumbuhan ekonomi inklusif. Maka berdasarkan hasil penelitian ini, sejalan dengan hasil penelitian (Raheem et al., 2018) menyatakan "the view that human capital development via spending on helath conclusive can aid the attainment of inclusive growth tends to be supported by the panel evidence reported in this study".

Variabel tingkat pengangguran terbuka (TPT) memiliki pengaruh tidak signifikan terhadap pertumbuhan ekonomi inklusif. Dengan nilai probabilitas 0.467>0.05. Artinya, ketika Tingkat Pengangguan Terbuka menurun sebesar 1 persen maka pertumbuhan ekonomi inklusif akan menurun sebesar 0.215043 persen secara rata-rata, dengan asumsi variabel lain tetap. Berdasarkan data pada Badan Pusat Statistik menunjukkan dalam satu dekade terakhir persentase tingkat partisipasi angkatan kerja (TPAK) cenderung menurun di beberapa tahun pada Gambar 9. Dengan adanya tingkat kemiskinan yang belum dapat ditekan. Hal ini dapat disebabkan karena adanya faktor internal tenaga kerja ataupun faktor 
eksternal tenaga kerja. Faktor eksternal tersebut dapat terjadi karena adanya pergeseran penyerapan tenaga kerja pada berbagai sektor atau lapangan usaha. Pendapatan masyarakat antar sektor usaha dapat bergeser, ketika jumlah pengangguran satu sektor di Indonesia mengalami peningkatan dan disamping itu terdapat penurunan jumlah pengangguran pada sektor lain. Menurut Badan Pusat Statistik, pada tahun 2018 ke tahun 2019 lapangan pekerjaan utama di Indonesia yang meningkat yaitu Penyediaan Akomodasi dan Makan Minum (0,05 persen), Industri Pengolahan (0,024 persen), dan Perdagangan (0,20 persen). Sementara itu pada tahun 2016 ke tahun 2017 lapangan pekerja utama yang meningkat diantaranya sektor Industri (0,93 persen), sektor Perdagangan (0,74 persen), dan sektor Jasa Kemasyarakatan (0,49 persen). Pada tahun 2014 ke tahun 2015 peningkatan lapangan pekerjaan utama ada pada sektor Kontruksi $(12,77 \%)$, sektor Perdagangan (3,42\%) dan sektor Keuangan (7,92\%). Pada tahun 2012 ke tahun 2013 peningkatan lapangan lapangan pekerjaan utama ada pada sektor Jasa Kemasyarakatan (6,49\%), sektor Perdagangan (2,50\%), dan sektor Keuangan (9,40\%). Selanjutnya, pada tahun 2010 ke 2011 peningkatan lapangan pekerjaan utama terjadi pada sektor 1 yaitu Pertanian, Perburuan, Perikanan menyerap tenaga kerja hingga $(35,86 \%)$. Dalam hal ini terdapat perubahan distribusi pendapatan masyarakat tersebut berdampak pada pergeseran daya beli yang sebelumnya dari pemilik faktor produksi kecil berubah perannya kepada pemilik faktor produksi yang tengah berkembang, sehingga yang terjadi di Indonesia adanya perubahan struktur ekonomi mengakibatkan adanya pergeseran pada sektor usaha dengan elastisitas penyerapan tenaga kerja yang rendah ke sektor usaha dengan elastisitas penyerapan tenaga kerja yang tinggi. Dengan hal tersebut pada sektor usaha dengan elastisitas penyerapan tenaga kerja yang rendah memungkinkan adanya peningkatan kemiskinan dan ketimpangan. Namun di sisi lain, pada sektor usaha dengan elastisitas penyerapan tenaga kerja yang cukup tinggi dapat mengurangi pengangguran dan meningkatkan taraf hidup masyarakat pada sektor tersebut hingga meningkatkan pendapatan dan lebih inklusif.

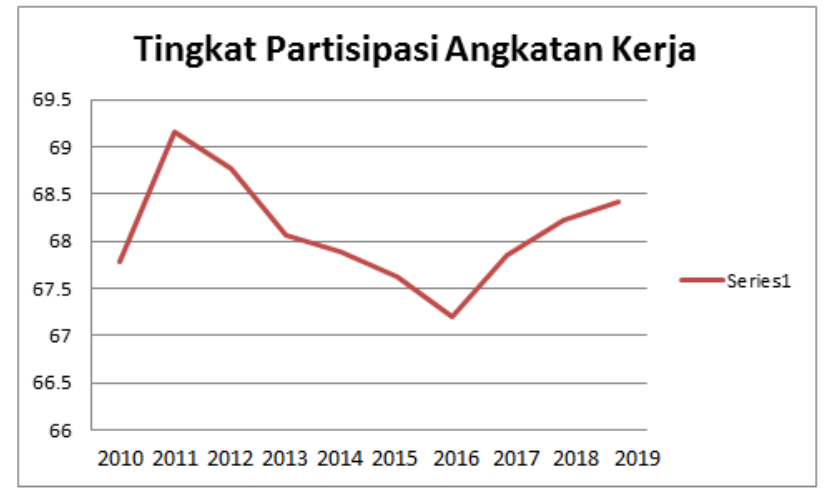

Gambar 9. Tingkat Partisipasi Angkatan Kerja di Indonesia tahun 2010-2019

Sumber: Badan Pusat Statistik Indonesia, (data diolah)

Pada hasil penelitian ini, sesuai dengan penelitian milik Azwar (2016) yang menyatakan bahwa variabel pengangguran memiliki pengaruh yang negatif dan tidak signifikan terhadap pertumbuhan ekonomi inklusif.

\section{Uji Asumsi Klasik}

Uji asumsi klasik dilakukan agar dalam penelitian ini diketahui layak tidaknya model regresi yang digunakan untuk menganalisa variabel-variabel yang ada dalam penelitian ini. Dalam pengujian regresi time series yang baik apabila telah memenuhi asumsi klasik. Asumsi-asumsi yang harus dipenuhi apabila analisis berganda berbasis OLS (ordinary least suare) digunakan, dimana variabel terikat sebagai penjelas dari variabel bebas.

Uji Normalitas

\begin{tabular}{r|ccccc}
\multicolumn{7}{c}{ Skewness/Kurtosis tests for Normality } & & \\
\cline { 3 - 5 } Variable & Obs & $\operatorname{Pr}$ (Skewness) & $\operatorname{Pr}$ (Kurtosis) adj chi2(2) Probrchi2 \\
\hline resid3 & 10 & 0.7863 & 0.8541 & 0.11 & 0.9478
\end{tabular}

Gambar 10. Hasil Uji Normalitas dengan menggunakan Uji Skewness Kurtosis

Sumber: data diolah (2020)

Berdasarkan Gambar 10 hasil dari uji tersebut menunjukkan nilai sebesar 0.9478. Keputusan yang diambil dalam penelitian ini dari nilai Prob>chi2 uji skewness kurtosis. Nilai Prob>chi2 sebesar 0.9478 
lebih besar dari taraf signifikansi 0.05 , maka dapat disimpulkan bahwa data distribusi residual dalam penelitian ini berdistribuasi normal dan terbebas dari asumsi klasik normalitas.

Uji Multikolinieritas

\begin{tabular}{|c|c|c|}
\hline Variable & VIF & 1/VIF \\
\hline ln_kes & 12.66 & 0.078971 \\
\hline In_pend & 10.65 & 0.093860 \\
\hline ln_tpt & 4.46 & 0.223982 \\
\hline Mean VIF & 9.26 & \\
\hline
\end{tabular}

Gambar 11. Hasil Uji Multikolinieritas

Sumber: Data diolah, 2020

Berdasarkan Gambar 11 menunjukkan bahwa rata-rata nilai Varian Inflation Factors (VIF) dalam model ini tidak melebihi 10.0. Maka dapat disimpulkan masing-masing variabel bebas dalam penelitian ini tidak memiliki korelasi satu sama lain, dengan kata lain variabel pengeluaran pemerintah bidang pendidikan tidak memiliki hubungan korelasi dengan variabel bebas lain, variabel pengeluaran pemerintah bidang kesehatan tidak memiliki hubungan korelasi dengan variabel bebas lain, dan variabel tingkat pengangguran terbuka tidak memiliki hubungan korelasi dengan variabel bebas lain.

Uji Heterokedastisitas

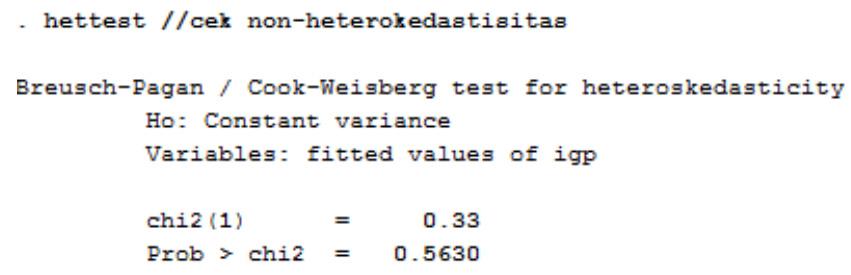

\section{Gambar 12. Hasil Uji Heteroskedastisitas}

Sumber: Data diolah, 2020

Berdasarkan Gambar 12 menunjukkan bahwa hasil dari Uji Breusch-Pagan dengan nilai Prob>chi ${ }^{2}$ lebih besar dari tingkat signifikansi 0.05 . Pengambilan keputusan dalam penelitian ini apabila nilai dari Prob>chi2 uji breusch-pagan lebih besar dari 0.05 maka model dalam penelitian tidak mengandung asumsi klasik heteroskedastisitas. Hasil dalam penelitian ini menunjukkan nilai 0.5630 yang lebih besar dari 0.05 . sehingga dapat disimpulkan bahwa dalam model penelitian ini terbebas dari asumsi klasik heterokedastisitas.

Uji Autokorelasi

\begin{tabular}{c|ccc}
\multicolumn{5}{c}{ Breusch-Godfrey LM test for autocorrelation } \\
\hline lags $(p)$ & chi2 & df & Prob $>$ chi2 \\
\hline 1 & 0.177 & 1 & 0.6744 \\
\hline \multicolumn{4}{c}{ Ho: no serial correlation }
\end{tabular}

Gambar 13. Hasil Uji Autokorelasi menggunakan LM Test

Sumber: Data diolah, 2020

Berdasarkan Gambar 12 menunjukkan bahwa nilai dari uji autokorelasi dengan menggunakan Lagrange Multiplier, pada hasil tersebut nilai dari Prob $>\mathrm{chi}^{2}$ lebih besar dari tingkat signifikansi 0.05 . Pengambilan keputusan dalam penelitian ini dari Uji Lagrange Multiplier dilakukan dengan melihat dari nilai Prob>chi2. Apabila nilai Prob $>\mathrm{chi}^{2}$ lebih besar dari 0.05 maka dalam model regresi tidak terjadi asumsi klasik autokorelasi. Dan sebaliknya, apabila nilai Prob>chi2 kurang dari 0.05 maka dalam model regresi ditemukan asumsi autokorelasi. Dalam model ini didapatkan nilai Prob>chi2 dari uji LM sebesar 0.6744 yang lebih besar dari 0.05 sehingga artinya dalam model regresi ini tidak ditemukan asumsi klasik autokorelasi.

\section{KESIMPULAN}

Berdasarkan hasil penelitian yang diperoleh, bahwa pertumbuhan ekonomi dalam mencapai inklusifitas terwujud pada tahun 2013-2015 dalam satu dekade terakhir dan tidak konsisten dalam 10 tahun terakhir. Hasil dari analisis regresi linier berganda data time series yaitu variabel pengeluaran 
pemerintah bidang pendidikan memiliki pengaruh yang signifikan terhadap pertumbuhan ekonomi inklusif, adapun kebijakan di bidang pendidikan oleh pemerintah selama periode pengamatan seperti perbaikan sistem pendidikan yang lebih modern, pembangunan sarana dan prasarana sekolah, dll, namun pengaruh dari hasil berbanding terbalik. Variabel pengeluaran pemerintah bidang kesehehatan memiliki pengaruh yang signifikan terhadap pertumbuhan ekonomi inklusif. Variabel tingkat pengangguran terbuka memiliki pengaruh yang tidak signifikan terhadap pertumbuhan ekonomi inklusif. Sehingga variabel pengeluaran pemerintah bidang pendidikan dan bidang kesehatan merupakan faktor pendukung tercapainya pertumbuhan ekonomi inklusif di Indonesia, namun melalui pengeluaran pemerintah bidang pendidikan belum maksimal hasil yang dicapai.

Berdasarkan hasil penelitian yang diperoleh, maka saran untuk penelitian selanjutnya diharapkan menggunakan metode yang berbeda dan menambahkan variabel di luar model yang dapat mempengaruhi secara signifikan percepatan pertumbuhan ekonomi inklusif di Indonesia.

Berdasarkan hasil penelitian menujukkan beberapa hal yang dapat menunjang mempercepat pertumbuhan ekonomi inklusif melalui implikasi kebijakan pemerintah, diantaranya melalui pengeluaran pemerintah bidang pendidikan terdapat penguatan kebijakan seperti meningkatkan pemberian insentif melalui Program Indonesia Pintar (PIP) yaitu Kartu Indonesia Pintar, beasiswa bagi masyarakat dengan kondisi ekonomi menengah kebawah secara merata hingga diadakan penguatan pendidikan vokasi yang baru saja ditegakkan. Dan disisi lain, pada program kesehatan melalui peningkatan penambahan sarana prasarana, jumlah tenaga medis hingga program Kartu Indonesia Sehat juga pada BPJS kesehatan. Juga melakukan pelatihan-pelatihan keterampilan terhadap tenaga kerja. Maka dengan adanya kebijakan tersebut merupakan beberapa upaya bagi pembangunan sumber daya manusia, dengan adanya perbaikan pada pembangunan sumber daya manusia akan mengarah pada produktivitas, terjadinya kesesuaian antara supply tenaga kerja terhadap permintaan tenaga kerja hingga peningkatan output secara agregat dan tercapainya pertumbuhan ekonomi yang lebih inklusif.

\section{DAFTAR PUSTAKA}

Amalina, D. H., Hutagaol, M. P., \& Asmara, A. (2013). Pertumbuhan Ekonomi Inklusif Di Kawasan Indonesia Bagian Barat Dan Indonesia Bagian Timur. Jurnal Ekonomi Dan Kebijakan Pembangunan, 2(2), 85-112.

Azwar. (2016). Pertumbuhan Inklusif Di Provinsi Sulawesi Selatan Dan Faktor-Faktor Yang Mempengaruhinya. Badan Pendidikan Dan Pelatihan Keuangan Kementrian Keuangan Republik Indonesia, 9(2), 1-31.

Bastias, D. D. (2010). Analisis Pengaruh Pengeluaran Pemerintah Atas Pendidikan, Kesehatan Dan Infrastruktur Terhadap Pertumbuhan Ekonomi Indonesia Periode 1969-2009. Semarang: Fakultas Ekonomi Universitas Diponegoro.

Badan Pusat Statistik. 2019. Jumlah Penduduk Miskin Indonesia Tahun 2009-2010. Jakarta.

Badan Pusat Statistik, B. (n.d.-a). Indeks Gini Indonesia.

https://www.bps.go.id/statictable/2014/09/08/946/distribusi-pembagian-pengeluaran-per-kapita-danindeks-gini-2010-2019.html

Badan Pusat Statistik, B. (n.d.-b). Tingkat Pengangguran Terbuka (TPT) Indonesia. https://www.bps.go.id/dynamictable/2020/02/19/1774/tingkat-pengangguran-terbuka-tpt-menurutprovinsi-1986---2019.html

Dianaputra, I. G. K. A., \& Aswitari, L. P. (2017). Pengaruh Pembiayaan Pemerintah Di Sektor Pendidikan Dan Kesehatan Terhadap Indeks Kualitas Manusia Serta Pertumbuhan Ekonomi Pada Kabupaten/Kota Provinsi Bali Tahun 2011-2015. E-Jurnal Ekonomi Pembangunan, 6(3), 286311.

Fathurahman, M., \& Haeruddin. (2011). Pemodelan Regresi Linier untuk Data Deret Waktu Linear Regression Modeling for Time Series Data. Eksponensial, 2(ISSN 2085-7829), 35-42.

Fitrianda, M. I. (2013). Pengaruh Jumlah Penduduk, Tingkat Partisipasi Angkatan Kerja (TPAK), Pengganguran Dan Kemiskinan Terhadap Pertumbuhan Ekonomi Provinsi Jawa Timur Tahun 1988-2018. Digital Repository Universitas Jember.

Ghozali, I., \& Ratmono, D. (2013). Analisis Multivariat Dan Ekonometrika. Universitas Diponegoro Semarang.

Habito, C. F. (2009). Patterns of Inclusive Growth in Developing Asia: Insights from an Enhanced Growth-Poverty Elasticity Analysis (ADBI Working Paper Series). Asian Development Bank Institute. http://www.adbi.org/working- paper/2009/08/12/3265.patterns.inclusive.growth.dev.asia/

Hidayah, Z. M. (2020). Pengaruh Indikator Pembangunan Ekonomi Terhadap Pertumbuhan Ekonomi Di Provinsi Jawa Timur. 
Kementrian Keuangan. (2019a). Anggaran Kesehatan. Direktorat PAPBN. http://www.dataapbn.kemenkeu.go.id/Dataset/Details/1008

Kementrian Keuangan. (2019b). Anggaran Pendidikan. Direktorat PAPBN. http://www.dataapbn.kemenkeu.go.id/Dataset/Details/1007

Klasen, S. (2010). Measuring and Monitoring Inclusive Growth : Multiple Definitions, Open Questions, and Some Constructive Proposals. ADB Sustainable Development Working Paper Series, Asian Development Bank, 12.

Maipita, I., Jantan, M. D., \& Razak, N. A. A. (2010). Dampak Kebijaka Fiskal Terhadap Kinerja Ekonomi Dan Angka Kemiskinan Di Indonesia. Buletin Ekonomi Moneter dan Perbankan, 12(4), 421-456.

Martono, N. (2010). Metode Penelitian Kuantitatif. Jakarta: PT Rajagrafindo Persada.

Meyer, D., \& Meyer, N. (2019). Assessment of Inclusive Growth performance: A comparative analysis of the BRICS countries. Acta Universitatis Danubius. Economica, 15(4), 191-207.

Mutijo, Kusriatmi, Suryono, Waluyo, Oktavia, G., Pafrida, M., Astuti, F. P., \& Nurita. (2016). Analisis Pertumbuhan Ekonomi Inklusif Daerah Istimewa Yogyakarta 2011-2015. Laporan Akhir. Bappeda DI Yogyakarta.

Prabandari, D. A. N., \& Santoso, D. B. (2018). Analisis Inklusivitas Pertumbuhan Ekonomi Di Jawa Timur Dan Faktor-Faktor Yang Mempengaruhinya. Jurnal Ilmiah Mahasiwa FEB Universitas Brawijaya, 7 (2), 1-12.

Prasetyo, T. H., \& Sulistyaningrum, E. (2013). Pengaruh Belanja Pemerintah Terhadap Pertumbuhan Ekonomi Studi Kasus: Provinsi Sulawesi Barat, 2006-2013.

Raheem, I. D., Isah, K. O., \& Adedeji, A. A. (2018). Inclusive growth, human capital development and natural resource rent in SSA. Economic Change and Restructuring, 51(1), 29-48. https://doi.org/10.1007/s10644-016-9193-y

Safira, Djohan, S., \& Nurjanana. (2019). Pengaruh Pengeluaran Pemerintah Pada Bidang Infrastruktur Pendidikan Dan Kesehatan Terhadap Pertumbuhan Ekonomi Di Provinsi Kalimantan Timur. Jurnal Ekonomi Manajemen Akuntansi Forum Ekonomi, 21(2), 211-216.

Sholihah, D. H. A. (2014). Pertumbuhan inklusif: faktor-faktor yang memengaruhi dan dampaknya terhadap pertumbuhan kelas menengah di Indonesia [Institut Pertanian Bogor]. https://repository.ipb.ac.id/handle/123456789/74697

Sheraphim, G. K. (2018). Pengaruh Tingkat Inklusi Keuangan, Tingkat Pengganguran Terbuka (TPT), Dana Pihak Ketiga (DPK), Dan Penanaman Modal Dalam Negeri (PMDN) Terhadap Tingkat Pertumbuhan Ekonomi Di 33 Provinsi Indonesia Periode 2011-2016. Jurnal Ilmiah Mahasiwa FEB Universitas Brawijaya, 1-22.

Sugianto, \& Permadhy, Y. T. (2020). Perencanaan Pembangunan Inklusif Melalui Peran Partisipatif Pemerintah Daerah. EcceS: Economics Social and Development Studies Abstract: Inclusive Development Planning Through The. 7(1), 87-109. https://doi.org/10.24252/ecc.v7i1.13565

Sukirno, S. (2011). Ekonomi Pembangunan (Agus (ed.); Kedua). Jakarta: Kencana Prenada Media Group. Suparno, H. (2014). Pengaruh Pengeluaran Pemerintah Sektor Pendidikan, Kesehatan, Dan Infrastruktur

Terhadap Pertumbuhan Ekonomi Dan Peningkatan Pembangunan Manusia Di Provinsi Kalimantan Timur. Journal of Innovation in Business \& Economics, 5(1), 1-22.

Tambunan, T. (2016). Pembangunan Ekonomi Inklusif (Pertama). Jakarta: LP3ES.

Todaro, M. P., \& Smith, S. C. (2006). Ekonomi Pembangunan (D. Barnadi, S. Suraydi, \& H. Wibi (eds.); sembilan). Jakarta: Erlangga.

Utama, Z. S., Khusaini, M., \& Wahyudi, S. T. (2017). Kebijakan Fiskal Di Persimpangan, Pro Growth Atau Pro Poor?. Jurnal Perbendaharaan, Keuangan Negara Dan Kebijakan Publik, 2(2), 67-81.

Wibowo, M. E. (2014). Analisis Pengaruh Pengeluaran Pemerintah Di Sektor Pertanian, Pendidikam, Kesehatan, Dan Infrastruktur Terhadap Tingkat Kemiskinan (Studi Kasus Di Kabupaten/Kota Provinsi Jawa Tengah). Tesis. Repository Universitas Diponegoro. http://eprints.undip.ac.id/44748/

World Bank. (n.d.). Produk Domestik Bruto Indonesia Tahun 2010-2019. https://data.worldbank.org/indicator/NY.GDP.MKTP.CD?lo 